\title{
The role of aesthetics in consumers' evaluation of apparel quality: A conceptual framework
}

\author{
Helena M de Klerk and Stephina J Lubbe
}

\section{OPSOMMING}

Die probleem waarom dit hier gaan is die rol van estetika in volwasse vroulike verbruikers se beoordeling van die kwaliteit van kledingprodukte. Uit die literatuur en vorige navorsing is dit duidelik dat dit in die daarstel van 'n totale estetiese ervaring nie net gaan om die bevrediging van die sensoriese nie, maar ook om die bevrediging van die kognitiewe en emosionele behoeftes van die mens. Emosionele en kognitiewe bevrediging mag dus ' $\mathrm{n}$ rol speel in die satisfaksie wat die verbruiker uiteindelik uit die kledingproduk ervaar, en mag ook ' $\mathrm{n}$ rol speel in die evaluering van die kwaliteit van kledingprodukte tydens die aankoopbesluitnemingsproses. Verbruikers verskil met betrekking tot hoe hulle kwaliteit van kledingprodukte evalueer. Verder onderstreep menige navorsers dit dat maksimum tevredenheid met die kledingproduk net kan realiseer as die verbruiker sensories, emosioneel en kognitief bevredig word. Die konseptuale raamwerk vir navorsing is teen die agtergrond van die voorafgaande ontwikkel. Dit is die mening van die navorsers dat die raamwerk sinvol gebruik kan word in kwalitatiewe en kwantitatiewe navorsing wat gaan om die faktore (in hierdie geval estetika) wat ' $n$ rol kan speel in die evaluering van die kwaliteit van kledingprodukte gedurende die verskillende stadia van die aankoopbesluitnemingsproses.

\section{- Prof HM de Klerk}

Department of Consumer Science

University of Pretoria

- Ms SJ Lubbe

Department of Consumer Science

University of Pretoria

\section{BACKGROUND}

From the theory and research relating to decisionmaking about apparel by consumers it is clear that the assessment of an item of apparel is an important step in deciding to purchase and that this includes aspects such as the assessment of the quality of the product (Fiore \& Damhorst, 1992). Furthermore, Swan and Combs, in Chen-Yu et al (1999), point out that consumer satisfaction with apparel products is influenced by the physical qualities as well as the psychological and that assessing the apparel product is not only limited to the functional aspects, but also includes the aesthetics. Fiore and Kimle (1997:55) point out that the interaction between the apparel item and the body can further complicate the purchasing decision for the consumer. Apparel products do not only elicit sensory reactions from consumers, but also emotional and cognitive, which, according to Fiore and Kimle (1997:4-13), usually result from the formal qualities of the item. For the consumer it therefore concerns not necessarily only the functional quality of the apparel item, but in fact the whole of the sensory, emotional and cognitive satisfaction that could provide the complete aesthetic experience.

From apparel theory it appears that consumers differ as to the role of aesthetics in their apparel behaviour (Shim \& Bickle, 1994; Fiore \& Kimle, 1997:55-56). Consumers also differ in the ways in which they evaluate the quality of apparel products. Consumers are often not even aware of the role aesthetics play in their apparel behaviour and are also usually uninformed about how the quality of apparel items should be assessed. This results in consumers deciding to purchase or not to purchase without due regard for the important factors that may have a role in the phases of the purchase decision-making process. This gives rise to a dissatisfied consumer (Brown \& Rice, 1998:42).

Cassill and Drake (1987) had already suggested in 1987 that female apparel consumers form the largest segment of the apparel consumers' market. In addition Walters and Bergiel (1989:39) point out that female clothing consumers are often not only responsible for the purchase of their own apparel items, but also of the household and the family. The question that concerns us here is: What is the role of aesthetics in the assessment by female apparel consumers of the quality of apparel products? Seen from consumer science the knowledge, perception and comprehension about this situation, could be used by apparel specialists and consumer consultants to increase consumer satisfaction. From the area of the marketing of apparel, Chen$\mathrm{Yu}$ et al (1999) point out that knowledge of the con- 
sumer's assessment about quality and factors that may influence the purchasing decision, can be employed usefully by retailers in the selection of products that they plan to tender as well as in promoting their sales and businesses. Unfortunately little research worldwide has been done since the late eighties about how apparel consumers evaluate the quality of apparel products during the purchase decision process. No specific research, directed to the role of aesthetics in assessing quality of apparel during this process, could be traced. The aim of the researchers is thus to develop a conceptual framework that can be used in assessing the role of aesthetics in consumers' evaluation of apparel quality.

In highlighting the problem, focus is placed on the role of aesthetics in:

- Apparel behaviour

- Quality assessment of apparel products.

\section{THE ROLE OF AESTHETICS IN APPAREL PRODUCTS}

For O'Neal (1998) aesthetics is defined as the study of human reaction to the non-instrumental qualities of an object or occurrence. According to De Long (1998:3) there is a relationship between aesthetics and the way that consumers clothe their bodies to be appreciated by themselves and also by others. This supports the presumption that aesthetics may, consciously or unconsciously, play an important role during the purchase decision process and to such an extent that it could overshadow other factors that should also have a role in assessing the quality of the item. In addition De Long (1998:5) points out that the aesthetic experience does not only include an experience dimension, but also an evaluation dimension. The latter may, depending on the consumer, form a larger or smaller component of the quality assessment process of apparel products. However, apparel products are not only assessed by the senses, but also with the emotions and the mind. If the views of Hogan (1994), De Long (1998:5) and Damhorst et al (1999:135), namely that the aesthetic experience involves the senses, emotions and mind, are accepted then the important role of aesthetics in quality assessing, during the purchase decision process to provide enjoyment or satisfaction for the consumer, can easily be understood.

According to Fiore and De Long (1994) the aesthetic experience, which comes from an item of apparel, addresses the internal processes, the multi-sensory properties, the psychological aspects and the sociocultural characteristics of the creator as well as the observer of the product or apparel appearance. Fiore and Kimle (1997:26) support this view and point out that a total aesthetic experience includes the appreciation of the formal, expressive and symbolic qualities of a product, appearance or environment. The authors emphasize that the aesthetic experience and consumers' satisfaction can therefore be directly connected with the aesthetic qualities of the apparel product or appearance that is used, consciously or uncon- sciously, by the consumer to create a specific aesthetic appearance for herself or someone else.

\section{The sensory dimension of the aesthetic experience}

Fiore and Kimle (1997:6) point to the fact that, to achieve a total aesthetic experience from a apparel item, it is important that the senses of the consumer are addressed and are satisfied. That which the consumer can see, feel, hear, taste and smell, has then to be acceptable for him and be included in his preferences. The authors also indicate that the sensory stimulation from the formal qualities of the apparel product, which include aspects such as colour, texture, line, form, rhythm, balance and proportion, can be used to stimulate the bodily senses, resulting in sensations of sensory enjoyment, discomfort or even pain. Researchers such as Ellen and Bone (1998), Hung (2000) and Matilla and Wirtz (2001) researched the importance of vision, tactile and olfactory sensations, hearing and movement in apparel consumers' decision-making and confirmed that the satisfaction of the senses fills an important role when consumers select apparel products. Although the formal qualities of apparel products are important in the sensory dimension of the aesthetic experience and could play an important role in the consumer's purchase decision process, the measure to which it consciously or unconsciously plays a role when consumers evaluate a product, is not clear.

\section{The emotional dimension of the aesthetic experience}

The rousing of the emotions and expression of feelings is after the stimulation of the senses, according to Fiore and Kimle (1997:42-45) important aspects not to be neglected in establishing an aesthetic experience concerning apparel. Researchers such as Havlena and Holbrook (1986) and Valdez and Mehrabian (1994) found that the rousing of the emotions and the provision of enjoyment are important components of the purchasing process of apparel consumers. Fiore and Kimle (1997:42-43) hold that, in satisfying the consumer at the emotional level, it is important that he should experience enjoyment (in other words should be happy and satisfied), that his emotions be addressed (that he should experience a feeling of elation) and that he will experience a feeling of dominance (therefore that he is in charge and that the item of apparel made its contribution). Apparel products thus not only have formal qualities, but also expressive qualities where these concern the expression of the feelings, whether these are related to certain inherent human emotional experiences of the specific consumer (as when a specific color provides a feeling of warmth or causes elation) or because it is an acquired association (that green could be a reflection of the restfulness of nature).

Fiore (1993) and Fiore and Kimle (1997:6) have the view that the expressive qualities of apparel products and the establishment of an emotional experience could play a determining role in creating an aesthetic 
experience in consumers. In addition authors such as Brown and Rice (1998:42) hold that in assessing quality the consumer is not only interested in the functional aspects of the apparel product, but also in the emotional dimension. What role the emotional dimension of the aesthetic experience plays, consciously or unconsciously, in assessing quality of apparel products is not clear.

\section{The cognitive dimension of the aesthetic experience}

From the social cognitive as well as a consumer approach it may be argued that consumers are active thinking beings that are actively involved in selecting consumer goods such as apparel products (Schiffman \& Kanuk, 2000:61). Fiore and Kimle (1997:45) agree with this view and indicate that cognitive enjoyment and satisfaction occurs in the mind. It follows therefore that the consumer creates content and meaning for himself from a specific apparel item. The authors are of the opinion that the cognitive dimension of the aesthetic experience should not be underestimated when considering consumers' selection of apparel products. It therefore hinges on the symbolic meaning that the apparel item might hold for the consumer, apart from satisfying his senses and having emotional content for him. Fiore and Kimle (1997:45) consider that, in providing the consumer with a cognitive aesthetic experience, the apparel product has to communicate a message of reality (such as conveying the message that the consumer belongs to a specific cultural or social group). The apparel product must also have a message of fantasy for the consumer (such as that dainty lingerie reflects the female consumer's inner sexuality). Finally the apparel product should provide cognitive enjoyment to the consumer (for example that he relates certain positive cognitive experiences from the past with it). The role that the cognitive dimension of aesthetics plays in the evaluation of apparel products and more specifically during the apparel consumer's purchase decision process have not yet been studied in depth.

\section{The interaction between the apparel product and the body}

According to Rudd and Lennon (1994) the body is the key in establishing an aesthetic appearance. Lynch et al (1998) and Damhorst et al (1999:135) add that the creation of an aesthetic appearance by adorning the body is not only limited to the sensory dimension of the appearance, but is also a deliberate emotional and cognitive self-expression of who and what the consumer is. Seen from the angle of aesthetics, Fiore and Kimle (1997:31) emphasize that the body, just as apparel products, contains specific formal qualities that also have expressive and symbolic value. Formal qualities of the body such as a boyish figure or an hourglass form, could therefore evoke certain emotional reactions from the consumer and onlooker (for example that the person appears soft and warm), while it also conveys a specific symbolic message to the consumer and onlooker (that the person has a specific status or is in control of the situation).
According to Abraham-Murali and Littrell (1995) the consumer has the ability to discern between the physical appearance of an apparel product and the body, and between the expressive and symbolic functions of both. To have a harmonious aesthetic interaction between body and apparel it is important that the formal aspects of the body and the apparel item should be reconcilable and complement each other, but also that the emotions which both evoke and the cognitive messages sent forth by both, are reconcilable and in harmony with each other. De Long (1998:12) and Rudd and Lennon (1994) agree with this view and they underline the proposition that an aesthetic experience originating from the specific appearance is not limited only to the aesthetic qualities of the apparel item or the body, but also includes the interaction between the aesthetic qualities of the apparel item and the body (Rudd and Lennon, 1994; Eckman, 1997; Fiore and Kimle, 1997:325).

From the above views the relationship between the different dimensions of an aesthetic experience can be illustrated schematically (Figure 1).

From Figure 1 it is clear that creating an aesthetic experience through an apparel product requires more than mere interaction between the formal aspects of the product and the bodily senses. It involves not only the physical aspects of the consumer, but also the cognitive and emotional and therefore these have perhaps an important role in the eventual satisfaction experienced by the consumer with the purchase. Establishing a complete aesthetic experience ought to play a role when consumers evaluate the quality of an apparel product during the purchase decision process.

\section{THE QUALITY OF APPAREL PRODUCTS}

\section{The Concept of quality}

Research about the meaning of quality and the ways in which consumers assess the quality of products has been increasingly advocated since the eighties. Unfortunately little has been done in this area since the late eighties. Hines and O'Neal (1998) have, however, determined that mature female apparel consumers are not consistent in their use of specific intrinsic indicators as indicative of the quality of apparel products and that only textile fabrics had consistently been used as an indicator of quality. It became evident that in many instances consumers did not deliberately evaluate the quality before, during or after the purchase and that the quality was deduced in many cases from specific extrinsic indicators, such as the brand name or the particular store where the purchase was made - practices that could be indicative of sparse consumer knowledge (Muller, 1984; Obermiller \& Wheatley, 1984; Grewal \& Monroe, 1995; Herbst \& Burger, 2002). Extrinsic variables are often used as indicators of product quality when the consumer has little or no experience about the product. Zeithaml (1988) holds that a distinction should be made between objective or mechanical quality and observed quality as the consumer experiences it from the prod- 


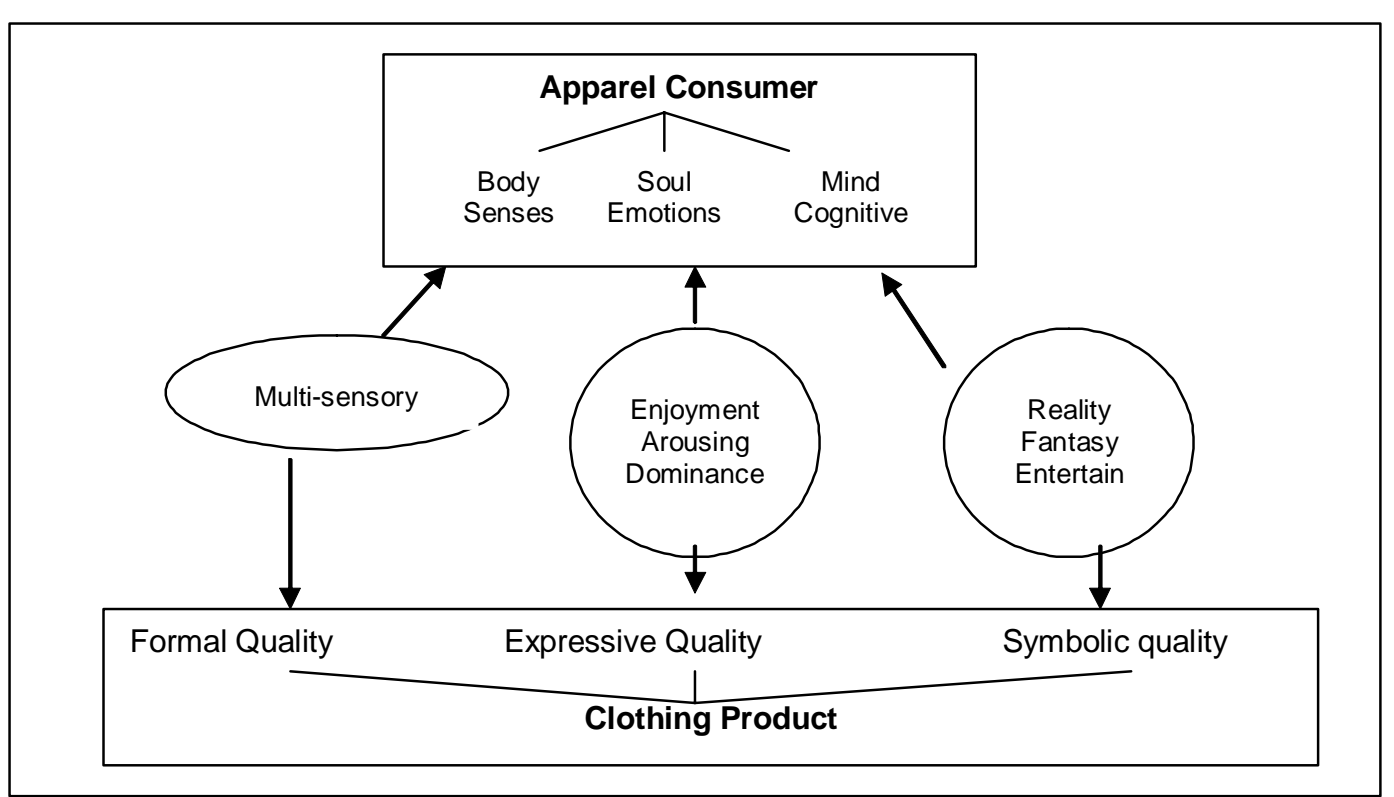

FIGURE 1: DIMENSIONS OF AN AESTHETIC EXPERIENCE FROM APPAREL PRODUCTS

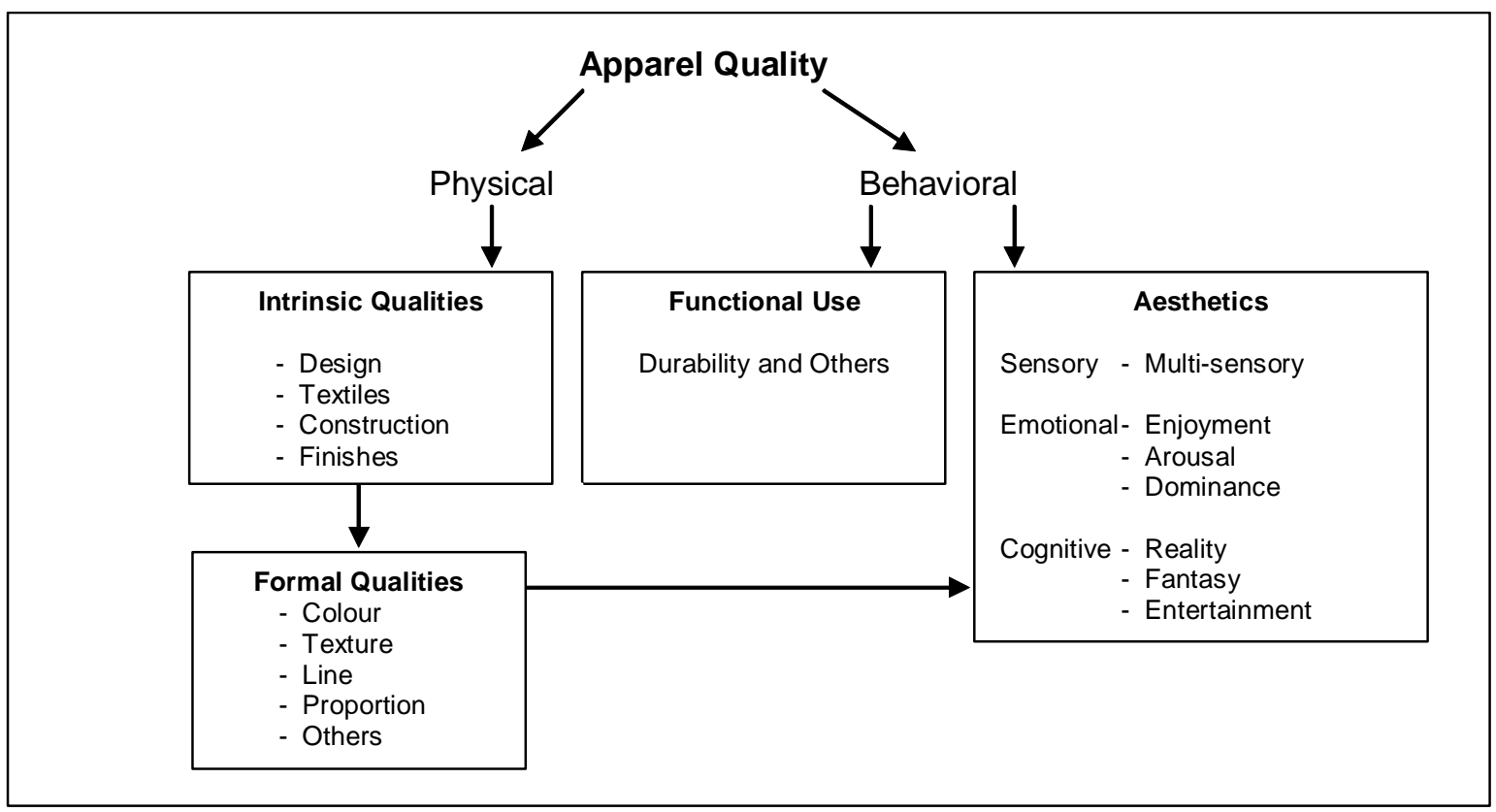

FIGURE 2: $\quad$ DIMENSIONS OF APPAREL PRODUCT QUALITY

uct, where the former is mainly concerned with the technical qualities of the product and the latter also includes the emotional and symbolic qualities. The concept of quality is therefore multi-dimensional and often vague

\section{Assessing the quality of apparel products}

Seen from the apparel marketing angle Yoon and Kijewski (1997) point out that the quality of apparel products is associated with the degree to which it fills the needs of the consumer. Brown and Rice (1998:38-39) add that the quality of apparel has two dimensions, namely the physical dimension that embraces what the item of clothing is, and a performance dimension indicating what the item of clothing can do. Since the physical properties influence the performance characteristics, consumers select apparel products because of the physical properties that they believe will then bring about the desired performance. Physical properties include the intrinsic properties of the product such as design, textiles used, construction and finishing and cannot be changed without changing the product itself. This also implies the formal aesthetic qualities of an apparel product such as the colour, line, form, texture and proportions. Intrinsic characteristics, accord- 


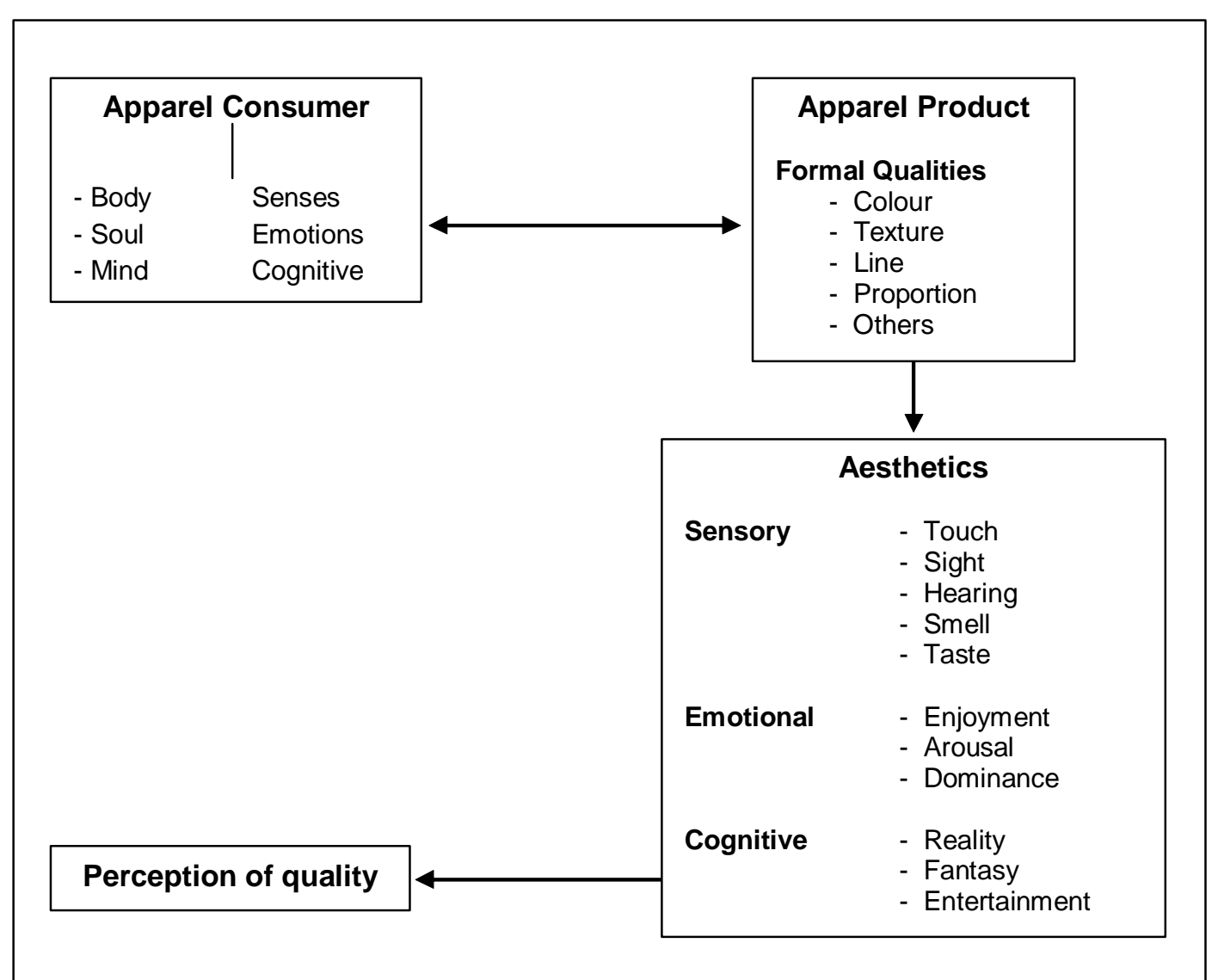

\section{FIGURE 3: CONCEPTUAL FRAMEWORK FOR THE ROLE OF AESTHETICS IN CONSUMER APPAREL BEHAVIOUR}

ing to Zeithaml (1988), play a role especially at the point of purchase where the product is physically judged. When consumers are not able to assess these characteristics, as is often the case with catalogue and Internet purchases, consumers experience a higher purchasing risk that could impede the purchase decision process (Jasper \& Quellette, 1994).

Brown and Rice (1998:38-39) and Gersak (2002) point out that the performance characteristics of apparel products may be divided into functional performance characteristics and aesthetic performance characteristics. Functional performance characteristics refer to those characteristics that are involved with the use and durability of the apparel product, such as being suitable for different purposes and occasions and that the item of apparel will keep its appearance and structure while being worn and cared for, while aesthetic performance characteristics refer to the beauty or the aesthetic experience it evokes in the consumer

From the foregoing and taking the theory of aesthetics into account, as schematically proposed in Figure 1, the following schematic conceptual representation of the concept apparel quality, as used in this framework, can be made (Figure 2).

From the above it is clear that satisfaction or dissatisfaction with an apparel product has more to it than just the reaction of the consumer to the performance characteristics of the product. Apparel consumers have specific expectations about the product because of previous experience with a similar product or culled from available information that could provide a guide to the quality (Muller, 1983; Solomon, 1996:325). The question to be answered is: Which criteria play a role when consumers form a perception about the quality of an apparel product? Karnes et al (1995) point out that maximum consumer satisfaction with an item of clothing may only be obtained if the consumer's physical, emotional, and cognitive expectations about the product are satisfied. Eckman et al (1990) and Fiore and Damhorst (1992) have determined that, depending on the type of apparel product, the aesthetic qualities of apparel products usually play a deciding role in the consumer's assessment of the total quality of the product and for the consumers it usually concerns the aesthetic functionality of the apparel product. Although relatively little research has been done about the role of aesthetics in quality assessment of apparel products, Walters and Bergiel (1989:69) point out that the approach of most of the apparel retailers is directed at the aesthetic qualities of the apparel and the view is usually taken that the aesthetic qualities of apparel are the most important elements when the consumer is assessing the product. Fiore and Damhorst (1992) indicate that aesthetic qualities have a role especially during the evaluating and trying-out 
stages of the purchase decision process, in other words at the point of purchase where the consumer has the opportunity of handling and trying-on the product. From the above the conceptual framework was developed as indicated in Figure 3.

It is clear from the schematic framework that when evaluating the quality of apparel items, the clothing consumer as body, soul and mind, is constantly in interaction with the formal qualities of the apparel product. These formal qualities include aspects such as colour, texture, line, proportion and others and may in the process of evaluation stimulate the consumer's senses, arouse her emotions or stimulate her cognitively, to such a degree that it may play a major role in her perception of the quality of the apparel item. The question for the researcher is thus, what role does the sensory, emotional and cognitive dimension of the aesthetic experience play in consumers' evaluation of the quality of apparel products?

\section{CONCLUSIONS, IMPLICATIONS AND APPLICATIONS}

Babbie and Mouton (1998:107-113) consider that the value of a soundly considered conceptual framework, based on a well-founded theory, where the indicators and possible relationships are present and which includes the research questions, is to be found in the fact that it arranges the research, assists the researcher to reach the research goals and to elicit results which in turn will be a contribution for establishing new theory. In the opinion of the researchers the conceptual framework (Figure 3 ) can be usefully applied in qualitative and quantitative research aimed at factors (in this case aesthetics) that could play a role in quality assessment by apparel consumers during the various stages of the purchase decision process.

The multi-dimensionality of the concepts quality and aesthetics are strongly emphasized. The researchers are of the opinion that a well-considered conceptual framework that contains all the indicators and possible relationships is a prerequisite for obtaining credible results, especially working with multi-dimensional concepts. These have to be taken into account by marketing and consumer researchers working in the area of product quality.

In addition, and keeping in mind the multidimensionality of the concepts, the researchers would suggest a qualitative research approach, qualitative data collecting methods, such as the unstructured interview as well as the use of stimulus material during the interviews. This should enable the researcher to obtain a suitable amount of data to interpret and in so doing add to the knowledge about consumer behaviour.

\section{REFERENCES}

ABRAHAM-MURALI, L \& LITTRELL, MA. 1995. Consumers' conceptualization of apparel attributes. Clothing and Textiles Research Journal 13(2):65-73.
BABBIE, E \& MOUTON, J. 1998. The practice of social research. Cape Town. Oxford.

BROWN, P \& RICE, J. 1998. Ready-to-wear apparel analysis. $2^{\text {nd }}$ ed. New Jersey. Merrill-Prentice Hall.

CASSILL, NL \& DRAKE, MF. 1987. Apparel selection criteria related to female consumer's lifestyle. Clothing and Textiles Research Journal 6(1):20-27.

CHEN-YU, HJ, WILLIAMS, G \& KINCADE, DH. 1999. Determinants of consumer satisfaction/dissatisfaction with the performance of apparel products. Family and Consumer Sciences Research Journal 28(2):167-192. DAMHORST, ML, MILLER, KA \& MICHELMAN, SO. 1999. The meanings of dress. New York. Macmillan.

DE LONG, MR. 1998. The way we look. Dress and aesthetics. $2^{\text {nd }}$ ed. New York. Fairchild.

ECKMAN, M, DAMHORST, ML \& KADOLF, SJ. 1990. Towards a model of the in-store purchase decision process: Consumer use of criteria for evaluating women's apparel. Clothing and Textiles Research Journal 8:13-22.

ECKMAN, M. 1997. Attractiveness of men's suits: The effect of aesthetic attributes and consumer characteristics. Clothing and Textiles Research Journal 15 (4):193-202.

ELLEN, PS \& BONE, PF. 1998. Does it matter if it smells? Olfactory stimuli as advertising executional Cues. Journal of Advertising 27(4):29-40.

FIORE, AM. 1993 Multi-sensory integration of visual, tactile, and olfactory aesthetic cues of appearance. Clothing and Textiles Research Journal 11(2):45-52.

FIORE, AM \& DAMHORST, ML. 1992. Intrinsic cues as predictors of perceived quality of apparel. Journal of Consumer Satisfaction, Dissatisfaction and Complaining Behavior 5:168-177.

FIORE, AM \& DE LONG, M. 1994. Introduction to aesthetics of textiles and clothing: Advancing multidisciplinary perspectives. ITAA Special Publication 7:1-6.

FIORE, AM \& KIMLE, PA. 1997. Understanding aesthetics for the merchandising and design professional. New York. Fairchild.

GERSAK, J. 2002. Development of the system for qualitative prediction of garments appearance quality. International Journal of Clothing Science and Technology 14(3):169-180.

GREWAL, D. \& MONROE, K.B. 1995. Information cues as signals of quality. European Advances in Consumer Research. 2:356-357.

HERBST, F \& BURGER, C. 2002. Attributes used by consumers when purchasing a fashion product: A conjoint analysis approach. Journal of Family Ecology and Consumer Sciences 30:40-45.

HAVLENA, WJ \& HOLBROOK, MB. 1986. The varieties of consumption experience: Comparing two typologies of emotion in consumer behavior. Journal of Consumer Research 13:394-404.

HINES, JD \& O'NEAL, GG. 1995. Underlying determinants of clothing quality: The consumer's perspective. Clothing and Textiles Research Journal 13(4):227232.

HOGAN, PC. 1994. The possibility of aesthetics. The British Journal of Aesthetics 34(4):337-347.

HUNG, K. 2000. Narrative music in congruent and incongruent TV advertising. Journal of Advertising 29 (1):25-34.

JASPER, CR \& QUELLETTE, SJ. 1994. Consumer's 
perception of risk and the purchase of apparel from catalogs. Journal of Direct Marketing 6(2):23-26.

KARNES, CL, SHRIDHARAN, SV \& KANET, JJ. 1995. Measuring quality from the consumer's perspective: A methodology and its application. International Journal of Production Economics 39:215-225.

LYNCH, A, MICHELMAN, SO \& HEGLAND, JE. 1998. Cross-cultural and intra-societal application of De Long's framework for visual analysis. Clothing and Textiles Research Journal 16(4):145-155.

MATILLA, AS \& WIRTZ, J. 2001. Congruency of scent and music as a driver of in-store evaluations and behavior. Journal of Retailing 77(2):273-287.

MULLER, JM. 1983. Verbruikerstevredenheid met tekstielprodukte. Journal for Dietetics and Home Economics 11(1):28-33.

MULLER, JM. 1984. Die Transvaalse tekstielverbruiker: Probleme en oplossings. Journal for Dietetics and Home Economics 12(1):8-13.

OBERMILLER, C \& WHEATLEY, JJ. 1984. Price effects on choice and perceptions under varying conditions of experience, information and beliefs in quality differences. Advances in Consumer Research 11:453458.

O'NEAL, GS. 1998. African-American aesthetic of dress: Current manifestations. Clothing and Textiles Research Journal 16(4):167-175.

RUDD, NA \& LENNON, SJ. 1994. Aesthetics of the body and social identity. ITAA Special Publication 7:1663-175.

SCHIFFMAN, LG \& KANUK, L. 2000. Consumer behavior. $6^{\text {th }}$ ed. New Jersey. Prentice Hall.

SHIM, S \& BICKLE, CB. 1994. Benefit segments of the female apparel market: Psychographics, shopping orientations and demographics. Clothing and Textiles Research Journal 12(2):1-11.

SOLOMON, MR. 1996. Consumer behavior: Buying, having, and being. $3^{\text {rd }}$ ed. New Jersey. Prentice Hall. VALDEZ, P \& MEHRABIAN, A. 1994. Effects of color on emotion. Journal of Experimental Psychology: General 123(4):394-409.

WALTERS, CG \& BERGIEL, BJ. 1989. Consumer behavior. A decision-making approach. Cincinnati. South-Western Publishing.

YOON, E \& KIJEWSKI, V. 1997 Dynamics of the relationship between product features, quality evaluation, and pricing. Pricing Strategy and Practice 5(2):45-60.

ZEITHAML, VA. 1988. Consumer perceptions of price, quality, and value: A means-end model and synthesis of evidence. Journal of Marketing 52:2-22. 